\title{
EVALUATION OF QUALITY INDICATORS RELATED TO QUALITY BREAD WHEAT PROMISING LINES
}

\author{
Mohammad Ali Ghadami, The MSC Student \\ Islamic Azad University Shahr-e-Rey Branch, Tehran, Iran \\ Mehdi Nasr Esfahani, Associate Professor \\ Central for Agriculture and Natural Resources Research, Esfahan, Iran
}
Seyed Hassan Mirhojjati, Mohammad Zamany Moghadam, Researchers
Islamic Azad University, Quchan, Iran

Mohammad Ali Shariati, Researcher

Science and Research Branch, Islamic Azad University, Tehran, Iran

Behnam Montazeri, Researcher

Shahrekord Branch, Islamic Azad University, Shahrekord, Iran

E-mail: $\underline{\text { m.ali.ghadami@gmail.com }}$

\begin{abstract}
The bread waste is one of the important socio-economic's issues country now, the urgent need is feeling to improve the wheat quality. Therefore, using the methods of farming and breeding is necessary to improve the quality of this strategic product. As a result, tests of quality's traits in wheat promising lines in Isfahan climate took place. In this study, the choice 17 advanced lines of compare the performances's experiments, an experiment was conducted for two consecutive cropping (2011-2012) at cultural experiment and research centre in Isfahan located in Kabutar Abad region. Randomized complete block designs with 3 replications were compared with Spring variety (for control). Traits including: 1000 grain weight, hectolitre weight, protein content, Zeleny sedimentation rate, bread volume, grain moisture content, grain hardness, water absorption, falling number, percentage of dry gluten, gluten index, sedimentation rates were SDS. The results of the combined analysis of variance qualitative characteristics's for two consecutive cropping showed that treatments with compare together and control variety had significant influence in $1 \%$ probability.Correlation coefficients of two years showed that the compound test significant positive correlation within grain hardness index and protein content, wet gluten and dry deposition rates of SDS. Also, significant positive correlation with the percentage of protein content of dry gluten. In view of the high correlation with protein content of dry gluten (quantity). However, grain hardness and relatively high correlation with SDS sedimentation as an important measure of protein quality. Therefore, the test results of dry gluten grains can be tough to choose in order to improve the quality of wheat bread may be used.
\end{abstract}

\section{KEY WORDS}

Qualitative traits, Wheat; Promising lines; Solidarity.

Wheat Products in dietary pattern in Iran is very important, as about 50 percent protein and 40 to 45 percent of calories needed daily to meet (6). The bakery value of diffrent wheat lines is depended to the amount of gluten in the grain. Gluten proteins are including Gliadin and glutenin and nearly $80 \%$ of the seed proteins are of two-component form (8). Grain protein content, is dependent on the variety, climatic conditions, etc.Baking quality mainly depends on two factors: the quality and quantity of gluten bread dough (4). The best way to check the quality of bread, preparation flour from the studied genotypes and standardized baking testing however, it can take time and cost. Thus, it can be an indirect way to measure bread quality traits, identified as criteria to estimate the value of bread wheat genotypes used (3). In the past was used total protein content for determine of wheat quality, but it is not 
suitable all proteins of wheat for bread-making quality and this property is only for gluten proteins. In addition to quantitative measurements, flour protein quality measurements were proposed. From existing methods can be noted to measure the sds sedimentation and zeleny sedimentation rate (3). Research in this direction in order to assess the quality attributes that affect seed quality in bread wheat, an experiment was conducted a randomized complete block design with four genotypes of wheat in three replications. Results indicated that seed hardiness index correlated significantly with protein content, SDS sedimentation and dry gluten content, also significant positive correlation within protein content, wet gluten content and dry gluten content was showed (1). Although the quality of grain to produce one of the important characteristics of high-yielding varieties of wheat breeding programs in the country, but a lot of work dont was done on it in iran. Research conducted on the quality was more on durum wheat (1). However, very little information about the quality of wheat bread. The key objectives of the present study were to determine the suitable selection of high-quality bakery bread cultivars that reduce waste, research on 17 lines of wheat compared with Spring variety (for control) at isfahan climate, in the field took place.

\section{MATERIALS AND METHODS}

These experiments were conducted in two consecutive cropping (2011-2012) at cultural experiment and research centre in Isfahan located in Kabutar Abad region. Soil texture was loam clay. $\mathrm{PH} 0$ to $30 \mathrm{~cm}$ soil depth averaged about $7 / 7$, the electrical conductivity of about $65 / 1 \mathrm{dS} \mathrm{m}^{-1}$ and soil bulk density $5 / 1$ gram per cubic centimeter is. A randomized complete block design whith 3 replications was used. Treatments Including 17 advanced lines of wheat were compared with Spring variety (for control) (Table 1). At harvest time of each treatment, 500 grams of flour, for qualitative properties tests, at the Cereal Chemistry Laboratory located in Seed and Plant Improvement Institute, Karaj, were tested. Hectolitre weight, based on the number of 55-10 instructions by the American Association of Cereal Chemists suggested, using the device, respectively. Alpha-amylase activity (falling number), based on the number of 55-81 (B) instructions by the American Association of Cereal Chemists suggested, and bread volume, grain protein percentage, kernel hardness and flour water absorption rate was determined by the method of Norris et al., (7). Also used Gluten Labeling Machine glutamic and centrifuge, wet gluten content obtained according to Standard No. 137 International Association of Cereal (5). Statistical analysis of the data by the statistical software spss were analyzed separately.

Table 1 - Genealogy profile of the lines*

\begin{tabular}{|c|c|}
\hline lines & Genealogy \\
\hline control & Spring variety (for control). \\
\hline $\mathrm{M}-87-2$ & $\mathrm{M}-83-17$ \\
\hline $\mathrm{M}-87-3$ & Seri/Avd/3/Rsh/Afn/4/jup/Bjy/Kauz \\
\hline $\mathrm{M}-87-4$ & Omid/H7/4/839/3/Omid/Tdo/5/Kal/Bb/Cj"s"/Hork"s" \\
\hline $\mathrm{M}-87-5$ & Alvd/Aldan"s"/las58/4/Kal/Bb/Cj"s"/3/Hork"s" \\
\hline $\mathrm{M}-87-6$ & Alvd/Aldan"s"/las58/4/Kal/Bb/Cj"s"/3/Hork"s" \\
\hline $\mathrm{M}-87-7$ & Alvd/Aldan"s"/las58/4/Kal/Bb/Cj"s"/3/Hork"s" \\
\hline $\mathrm{M}-87-8$ & Tbs/FIt/3/Evwy2/Azd/Rsh*2/10120/4/M-75-7 \\
\hline $\mathrm{M}-87-9$ & 1-66-22/5/1-66-31/4/Anza/3/Pi/Nar/Hyz/6/M-75-7 \\
\hline $\mathrm{M}-87-10$ & 1-66-22/5/1-66-31/4/Anza/3/Pi/Nar/Hyz/6/M-75-7 \\
\hline$M-87-11$ & Hereward/Siren/5/Gov/Az/Mus/3/DoDo/4/Bow \\
\hline $\mathrm{M}-87-12$ & Merual/4/Bloudan/3/Bb/7c*2/Y50E/Kal*3/5/shiroodi \\
\hline $\mathrm{M}-87-13$ & Gascogne/3/Nai60/Hn7//sy \\
\hline $\mathrm{M}-87-14$ & OASIS/SKAUZZ//4*BCN*2/3/PASTORR \\
\hline $\mathrm{M}-87-15$ & TURACO/CHIL/SKAÜZ/3/PASTOR \\
\hline $\mathrm{M}-87-16$ & KAUZZ//ALTAR 84/AOS/3/PASTOR \\
\hline $\mathrm{M}-87-17$ & VEE/PJN/2*KAUZ/3/PASTOR \\
\hline $\mathrm{M}-87-18$ & BABAX/LR42//BABAX \\
\hline
\end{tabular}

* Derived from Isfahan Research Center for Agriculture and Natural Resources's Germplasm 


\section{RESULTS AND DISCUSSION}

The results showed that, lines test cases from all characteristics of qualitative including: grain weight, hectolitre weight, protein content, Zeleny sedimentation rate, bread volume, grain moisture content, grain hardness, water absorption, falling number, wet and dry gluten content, gluten index and SDS sedimentation rate, with compare together and control variety had significant influence in $1 \%$ probability (Table 2 ).

Table 2 - ANOVA results of quality and quantity parameters of treated wheat lines (two years) [Part 1]

\begin{tabular}{|c|c|c|c|c|c|c|}
\hline $\begin{array}{c}\text { Sources of } \\
\text { changes }\end{array}$ & zeleni & Protein & $\begin{array}{c}\text { Weight of } 1000 \\
\text { seeds }\end{array}$ & $\begin{array}{l}\text { Dry } \\
\text { gluten }\end{array}$ & $\begin{array}{l}\text { Degree of } \\
\text { freedom }\end{array}$ & volume \\
\hline Year & $2 / 098^{\mathrm{ns}}$ & $0 / 0188^{\mathrm{ns}}$ & $1 / 068^{\mathrm{ns}}$ & $0 / 014^{\text {ns }}$ & 2 & $137 / 345^{n s}$ \\
\hline Genotype & $8 / 691 * *$ & $0 / 276$ ** & $56 / 564$ ** & $2 / 163 * *$ & 17 & $2921 / 436 * *$ \\
\hline Year & $104 / 083$ & $12 / 813$ & $3004 / 113$ ** & $700 / 02$ ** & 1 & $76960 / 083$ \\
\hline Genotype * year & $6 / 103 * *$ & $0 / 312 * *$ & $29 / 489 * *$ & $1 / 812 * *$ & 17 & $2237 / 672 * *$ \\
\hline Error & $807 / 006$ & $0 / 006$ & $0 / 867$ & $0 / 043$ & 70 & $75 / 745$ \\
\hline $\begin{array}{l}\text { Changes } \\
\text { coefficient }\end{array}$ & $3 / 55$ & $1 / 77$ & $8 / 14$ & $6 / 05$ & - & $4 / 64$ \\
\hline R-Square & $0 / 876$ & $0 / 983$ & $0 / 987$ & $0 / 961$ & - & $0 / 969$ \\
\hline
\end{tabular}

Table 2 - ANOVA results of quality and quantity parameters of treated wheat lines (two years) [Part 2]

\begin{tabular}{|c|c|c|c|c|c|c|}
\hline $\begin{array}{c}\text { Sources of } \\
\text { changes }\end{array}$ & $\begin{array}{l}\text { Falling } \\
\text { Number }\end{array}$ & $\begin{array}{l}\text { Water } \\
\text { intake }\end{array}$ & Hardness & SDS & $\begin{array}{c}\text { Degree of } \\
\text { freedom }\end{array}$ & Wet gluten \\
\hline Year & $0 / 715$ ns & $0 / 013^{\text {ns }}$ & $0 / 668^{\text {ns }}$ & $0 / 247^{\text {ns }}$ & 2 & $0 / 174$ ns \\
\hline Genotype & $27660 / 890 * *$ & $1 / 620 * *$ & $12 / 624^{* *}$ & $38 / 876^{* *}$ & 17 & $3754 / 260$ * \\
\hline Year & $114367 / 688$ ** & $5 / 741$ ** & $205 / 556$ & $357 / 157$ & 1 & $334 / 333$ * \\
\hline Genotype * year & $27080 / 601$ ** & $1 / 536$ ** & $11 / 094$ ** & $30 / 290$ ** & 17 & $2195 / 674$ \\
\hline Error & $0 / 415$ & $0 / 018$ & $0 / 396$ & $0 / 383$ & 70 & $0 / 059$ \\
\hline $\begin{array}{l}\text { Changes } \\
\text { coefficient }\end{array}$ & $11 / 33$ & $0 / 81$ & $2 / 59$ & $4 / 75$ & - & $4 / 92$ \\
\hline R-Square & $1 / 00$ & $0 / 979$ & $0 / 998$ & $0 / 983$ & - & $1 / 00$ \\
\hline
\end{tabular}

$n s$ (no significant), * significant $(p<0.05),{ }^{* *}$ significant $(p<0.01)$

As might was expected, the highest correlation was observed between wet gluten content and dry gluten content $\left(r=0 / 927^{* *}\right)$. Although the gluten content reflects the quantity of protein, highly significant positive correlation was found between protein content and dry gluten content $\left(r=0 / 760^{* *}\right)$, and wet gluten with protein content $\left(r=0 / 653^{* *}\right)$. Correlation between the characteristics of wet and dry gluten, gluten index and SDS sedimentation volume was positive and significant. Also, grain hardness index indicated significant positive correlation with protein content, water absorption, wet and dry gluten; Zeleny and SDS sedimentation rates (Table 3). Research has shown that the correlation between the protein percentage with hardness seed, grain moisture and water absorption, loaf volume, Zeleny and SDS sedimentation volume characteristics is positive and significant $(2,9)$. One of the most important factors in evaluating the quality of wheat bread volume is particularly large in the case of bread is very important. Bread volume is introduces to market characteristics. According to the results of the correlation coefficients, bread volume with wet and dry gluten content and Zeleny has a significant positive correlation. Arzani (1) in study the effect of environment on wheat quality traits, reported that environmental conditions have a significant effect on bread volume was observed. Also, correlation between bread volume and Zeleny number, a significant percentage of gluten and protein reported. 
Table 3 - Correlation coefficient of quality parameters of promising lines of wheat

\begin{tabular}{|c|c|c|c|c|c|c|c|c|c|c|c|c|c|}
\hline$n / n$ & SDS & $\begin{array}{c}\text { Dry } \\
\text { Gluten } \\
\text { (\%) }\end{array}$ & $\begin{array}{l}\text { Gluten } \\
\text { indec }\end{array}$ & $\begin{array}{c}\text { Wet } \\
\text { Gluten } \\
\text { (\%) }\end{array}$ & $\begin{array}{l}\text { Falling } \\
\text { Number }\end{array}$ & $\begin{array}{c}\text { Water } \\
\text { intake (\%) }\end{array}$ & hardness & $\begin{array}{c}\text { Humidity } \\
(\%)\end{array}$ & $\begin{array}{c}\text { Bread } \\
\text { volum }(m)\end{array}$ & $\begin{array}{l}\text { Zeleny } \\
(\mathrm{m})\end{array}$ & $\begin{array}{c}\text { Protein } \\
\text { (\%) }\end{array}$ & $\begin{array}{l}\text { Hectoliter } \\
\text { weight }(\mathrm{kg})\end{array}$ & $\begin{array}{l}\text { Weight of } \\
1000 \text { seeds } \\
\text { (gr) }\end{array}$ \\
\hline $\begin{array}{l}\text { Weight of } \\
1000 \text { seeds }\end{array}$ & & & & & & & & & & & & & 1 \\
\hline Hectoliter & & & & & & & & & & & & 1 & 0/095 \\
\hline Protein & & & & & & & & & & & 1 & $-0 / 340$ & $-0 / 473 *$ \\
\hline Zeleny & & & & & & & & & & 1 & $0 / 551$ & $-0 / 541 * *$ & $-0 / 282$ \\
\hline Bread volume & & & & & & & & & 1 & $0 / 404$ * & $0 / 270$ & $0 / 168$ & $-0 / 149$ \\
\hline Humidity & & & & & & & & 1 & $-0 / 152$ & $0 / 041$ & $-0 / 100$ & $-0 / 398$ & $0 / 341$ \\
\hline hardness & & & & & & & 1 & $-0 / 066$ & $0 / 143$ & $0 / 485$ * & $\underset{* *}{0 / 709}$ & $-0 / 340$ & $-0 / 431 *$ \\
\hline Water intake & & & & & & 1 & $0 / 559$ ** & $-0 / 346$ & $-0 / 114$ & 0/291 & $0 / 620$ & $-0 / 054$ & $-0 / 311$ \\
\hline Falling number & & & & & 1 & 0/036 & $-0 / 166$ & $-0 / 061$ & $-0 / 038$ & $0 / 119$ & $0 / 000$ & $-0 / 035$ & $0 / 212$ \\
\hline Wet gluten & & & & 1 & $-0 / 146$ & $0 / 516$ * & 0/610 ** & $-0 / 272$ & 0/352 & 0/481 * & $0 / 653$ & $-0 / 205$ & $-0 / 531 *$ \\
\hline Gluten index & & & 1 & 0/498 * & 0/012 & $0 / 420$ * & $0 / 607 * *$ & $-0 / 047$ & 0/207 & $0 / 260$ & $0 / 406$ * & $-0 / 201$ & $-0 / 048$ \\
\hline Dry gluten & & 1 & $0 / 441^{*}$ & $0 / 927^{* *}$ & $-0 / 105$ & $0 / 614^{* *}$ & $0 / 614^{* *}$ & $-0 / 412^{*}$ & $0 / 420$ * & $0 / 594$ ** & $0 / 760$ & $-0 / 015$ & $-0 / 551 * *$ \\
\hline SDS & 1 & $0 / 456$ * & $0 / 549 * *$ & $0 / 423^{*}$ & $0 / 204$ & $0 / 394$ & $0 / 719$ ** & $0 / 207$ & $0 / 076$ & $0 / 030$ & $0 / 142$ & $-0 / 167$ & $0 / 113$ \\
\hline
\end{tabular}

$n s$ (no significant), * significant $(p<0.05),{ }^{* *}$ significant $(p<0.01)$ 
Shahin nia et al., The survey showed that in the most of most lines with high bread volume, the volume will be high Zeleny, although in the some lines with high Zeleny volume may be relatively low bread volume. This is due to the effect of the protein percentage on the number of Zeleny. Correlation between seed weight and other quality traits such as protein content, dry gluten content were negative and significant. In this regard, Norris et al., (7) found that weight loss of saving grain starch led to protein content per unit volume is increased, because one of the first enzymes of starch synthesis, adenylate phosphate transferase is Glvkzyk, that in the stress condition, its value is reduced significantly. Thus, in the qualitative characteristics, protein content, dry gluten, grain hardness were significantly correlated with a greater number of characteristics (Table 3).

In this regard, In order to explore the diversity and path coefficient analysis of breadmaking quality traits by path coefficient analysis, 145 bread wheat genotypes in augmented design compared with three controls: Roshan, Ghods and Mahdavi, were evaluated. The results demonstrate the importance significant and direct effect Bread sedimentation SDS, bread volume, grain moisture and water absorption and were indirect effects of these characteristics by protein percentage on the SDS sedimentation volume changes. The results of the study of correlation between qualitative traits, on direct and significant relationship between protein content and SDS sedimentation volume with other bread quality traits were testified (8). In an experimental study of plant density on quality characteristics of wheat Kouhdasht, at Gonbad dry conditions in a factorial randomized complete block design was conducted. Correlation analysis indicates, was significant positive correlation between Zeleny and bread volume and grain hardness (5). In this regard, in one study that conducted to assess the qualitative characteristics influencing grain quality of wheat bread, The experiment used a randomized complete block design with four genotypes of wheat in the crop year 80-1379 was administered in 3 replicates, the results indicated that seed hardiness correlated significantly with protein content, SDS sedimentation and dry gluten content, also,was significant positive correlation between protein content, with wet gluten content and dry gluten content showed (2). According to the results of the correlation coefficients (Table 3 ), in the justification noted the relationship should be due to filling the empty space between the cells with the protein particles, hard grains wheat and glassy, have more protein than of soft wheat. Therefore, grain hardness with other properties directly with the protein shows significant correlation, and indirectly affect with the amount of water absorbed by the flour and Zeleny volume will be effective (9). SDS sedimentation showed significantly positive correlation with grain hardness. In fact, with increase in grain hardness, proteins' affecting the seed quality is enhanced. Given that the gluten content reflects the quantity of protein, positive correlation between protein content and gluten content seem logical. It should be noted, due to the relatively high correlation between dry gluten with protein content (quantity), on the other hand grain hardness have high correlation with SDS sedimentation as an important measure of protein quality, so the dry gluten and grains hardness for choices in order to improve the quality of wheat bread can be used.

\section{REFERENCES}

[1] Arzani, A.2002. Grain quality of durum wheat germplasm as affected by heat and drought stress at grain filling period. Wheat Imformation Service 94:9-14.

[2] Eslami,M, Meybodi,S.A.D,2005.Grain Quality Traits and capabilities of their heritability In durum wheat genotypes Agricultural Sciences and Natural Resources.year 9. No 3. 121:128.

[3] Gupta, R.B., F.Bekes and Y. Popineaut.1995.Biochemical basis of flour properties in bread wheat .J.Cereal Sci. 103:116.

[4] Khalil Zadeh, AS, Gharib eshghi, A .2002. evaluate cultivars and advanced lines of bread wheat for resistance to cold / Proceedings of the Eighth Conference of Crop Sciences, Iran, Gilan University, $234: 239$.

[5] Maassoudifar, O. Mohammadkhani, M.A., 2005. Study of effects plant density on quality characteristics in wheat. Iranian Journal of Biology. Volume 18. no1. 69:71. 
[6] Naserian .B., Asadi .A.A., Rahimi .M., Ardakani .M.R., 2007, Evaluation of wheat cultivar and Mutans for Morphological and yield Traits and comparing of yield components under Irrigated and Rain Fed condition , Asian Journal of Plant Sciences, 214:224.

[6] Norris ,K.H. ,W.R.Hruschka,M.M. Bean and D.C.Slaughter.1989.A definition of wheat hardness using near infrared reflectance spectroscopy. Cereal Foods World .No34.696:705.

[7] Payan, R, 1995, Introdaaction to technology of cereal proudation, Aeej, Tehran, p. 420.

[8] Shahinia F., Rezaee A.M., 2002. Evaluation the diversity and path coefficient analysis of traits associated with quality bakery. Agricultural Sciences and Natural Resources. No2. 77:88. 